\title{
Pengalaman Keluarga sebagai Caregiver dalam Merawat Pasien Strok di Rumah
}

\author{
Nanda Masraini Daulay, Setiawan, Nunung Febriany S \\ Fakultas Keperawatan Universitas Sumatera Utara \\ E-mail:nanda_daulay88@yahoo.com
}

\begin{abstract}
Abstrak
Sebagian besar pasien strok yang kembali ke rumah mengalami kecacatan. Kecacatan akibat strok tidak hanya berdampak bagi pasien, akan tetapi juga berdampak bagi anggota keluarga yang akan menjadi caregiver. Penelitian pada caregiver ini penting karena caregiver berperan terhadap keberhasilan pengobatan dan perawatan pasien strok. Penelitian ini bertujuan untuk mengeksplorasi secara mendalam tentang makna pengalaman keluarga sebagai caregiver pasien strok di rumah. Penelitian ini merupakan studi fenomenologi deskriptif. Pengumpulan data dilakukan dengan indepth interview. Partisipan dalam penelitian ini berjumlah 16 orang yang dipilih dengan teknik purpossive sampling. Data yang diperoleh dianalisis dengan pendekatan Colaizzi. Hasil analisis penelitian ditemukan lima tema yaitu: memberikan dukungan total, memenuhi kebutuhan dasar, penderitaan dan hikmah bagi caregiver, kurangnya keterampilan dalam merawat, dan keterbatasan caregiver. Caregiver menderita masalah fisik, psikologis, dan sosial. Pada umumnya, caregiver merasa terabaikan, mereka membutuhkan informasi terkait penyakit pasien, cara merawat pasien strok, dan sumber-sumber komunitas pelayanan kesehatan. Berdasarkan hasil penelitian, perawat disarankan untuk melakukan perencanaan pulang individual yang lebih berpusat pada keluarga daripada pendekatan berpusat pada pasien.
\end{abstract}

Kata kunci: Caregiver keluarga, merawat, pasien strok.

\section{The Live Experience of Caregiver Caring for Patient with Stroke at Home}

\begin{abstract}
Most of the strok patients who return home suffer from disabilities. Disability caused by strok not only impact on strok patients, but also impact on family members who will be the caregiver. The concern to the caregiver is important because the success of the treatment and care of strok patients can not be separated from the help and support provided by the caregiver. This study aims to explore deeply the meaning of family experience as caregiver for strok patients at home. This study is a descriptive phenomenological study. Data were collected through indepth interview. Participants in this study were 16 people who were selected by purposive sampling technique. The data obtained were analyzed by using Colaizzi approach. Results of analysis found 5 (five) themes, namely: giving total support, meeting basic needs, suffering and wisdom for the caregiver, lack of skills in caring for, and limitations of caregiver. Caregiver suffering from physical, psychological, and social problems. In general, caregivers feel neglected, they need information about the patient's illness and how to care for them as well as community resources for health services. Based on the results of the research, it is suggested that discharge planning approach should be focused more on family rather than patient.
\end{abstract}

Key words: Family caregiver, caring, strok patient. 
Nanda Masraini Daulay: Study Fenomenologi: Pengalaman Keluarga sebagai Caregiver

\section{Pendahuluan}

Penyakit strok merupakan penyebab kematian nomor tiga di dunia dan penyebab kecacatan paling sering pada orang dewasa (Abubakar \& Isezuo, 2012). Indonesia tercatat sebagai negara dengan jumlah penderita strok terbesar di Asia. Setiap tujuh orang yang meninggal di Indonesia, satu diantaranya karena strok (Departemen Kesehatan Republik Indonesia, 2011). Jumlah penderita strok di Indonesia mencapai 500.000 penduduk setiap tahunnya, sekitar 2,5\% atau 125.000 orang meninggal, dan sisanya yang mengalami cacat ringan maupun cacat berat (Yayasan Strok Indonesia, 2009).

Salah satu penelitian yang dilakukan di Amerika menyebutkan bahwa sebesar 38\% penderita strok mengalami depresi yang disebabkan ketidakmampuan dalam bekerja karena cacat dan berkurangnya kegiatan sosial. Kecacatan akibat strok tidak hanya berdampak bagi penyandangnya, akan tetapi juga berdampak bagi anggota keluarga. Penderita strok yang mengalami kecacatan bergantung pada dukungan emosional dan fisik dari informal caregiver yang biasanya adalah anggota keluarga (Akosile, Okoye, Nwankwo, Akosile \& Mbada, 2011).

Keluarga pasien sebagai caregiver yang selalu setia mendampingi selama hampir 24 jam disamping pasien untuk memberikan perawatan dan dukungan emosional sering terlupakan diteliti. Perhatian pada caregiver ini penting karena keberhasilan pengobatan dan perawatan pasien strok tidak dapat lepas dari bantuan dan dukungan yang diberikan caregiver. Given, Given \& Sherwood (2011), menyatakan bahwa caregiver adalah sumber dukungan utama individu dengan strok dan merupakan orang pertama yang merespon perubahan status pasien selama fase perjalanan penyakitnya.

Beberapa penelitian tentang caregiver menunjukkan hasil bahwa caregiver merasa terbebani dalam merawat pasien strok dan berdampak negatif terhadap kesehatannya. Sekitar sebanyak 30-48\% caregiver keluarga mengalami stres psikologis yang lebih besar dibandingkan dengan pasien yang dirawatnya. Penelitian kualitatif tentang persepsi keluarga sebagai caregiver di Tanzania, oleh Wodchis, dkk. (2007), menunjukkan adanya dampak emosional negatif pada caregiver.

Pengalaman yang berbeda dapat dialami oleh caregiver dalam merawat pasien strok di rumah. Melihat berbagai fenomena terkait peran keluarga sebagai caregiver pasien strok, peneliti tertarik untuk mengeksplorasi lebih mendalam bagaimana pengalaman keluarga sebagai caregiver dalam merawat pasien strok di rumah. Penelitian ini dilakukan dengan pendekatan fenomenologi karena masih sangat sedikit penelitian terkait pengalaman keluarga sebagai caregiver dalam merawat pasien strok di rumah yang dilakukan dengan desain kualitatif. Selain itu, dengan menggunakan pendekatan fenomenologi akan diperoleh informasi baru yang lebih banyak secara komprehensif dan mendalam terkait fenomena keluarga sebagai caregiver dalam merawat pasien strok di rumah yang belum tentu dapat diperoleh melalui desain penelitian lain.

\section{Metode Penelitian}

Penelitian ini menggunakan studi kualitatif dengan desain fenomenologi deskriptif. Fenomenologi deskriptif adalah penelitian yang melibatkan eksplorasi langsung, analisa data dan deskripsi dari fenomena tertentu, sebebas mungkin dari dugaan yang belum teruji. Desain penelitian ini bertujuan untuk mendapatkan hasil yang maksimal dari pengalaman individu tentang sesuatu, baik itu yang dilihat, dirasakan, diingat, dipercayai, diputuskan, dan dilakukan serta seterusnya. Desain fenomenologi deskriptif dipilih agar penelitian ini dapat mengeksplorasi lebih mendalam pengalaman keluarga sebagai caregiver dalam merawat pasien strok di rumah.

Penelitian ini dilakukan di kota Medan dengan melakukan wawancara di rumah partisipan. Partisipan dalam penelitian ini 16 orang caregiver keluarga pada pasien strok yang dirawat di rumah. Jumlah partisipan ditentukan dengan teknik purposive sampling dengan kriteria inklusi yaitu, partisipan merupakan caregiver keluarga, partisipan merupakan non-profesional dan tidak dibayar, partisipan merupakan yang minimal telah merawat selama satu bulan, dan partisipa yang bukan caregiver primer bagi pasien lain. 
Nanda Masraini Daulay: Study Fenomenologi: Pengalaman Keluarga sebagai Caregiver

Teknik pengumpulan data pada penelitian ini dengan menggunakan metode wawancara secara mendalam (in-depth interview) yang dilakukan oleh peneliti sendiri dengan durasi 60-90 menit. Metode wawancara mendalam ini menggunakan panduan wawancara yang berisi butir-butir pertanyaan untuk diajukan kepada para partisipan. Panduan wawancara tersebut berisi pertanyaan yang diajukan kepada patisipan, pertanyaan tersebut dibuat sendiri oleh peneliti. Panduan wawancara dibuat berdasarkan landasan teori yang relevan dengan masalah yang akan digali dalam penelitian. Panduan wawancara dibuat untuk memudahkan peneliti supaya jalannya wawancara terarah dan sesuai dengan tujuan penelitian. Selain itu, panduan wawancara digunakan untuk mengingatkan peneliti terhadap pokok permasalahan yang dibahas. Panduan wawancara tersebut telah dilakukan content validity oleh tiga expert dengan hasil content validity index (CVI) 0.94 (nilai CVI $>0.8$ ), hal ini berarti panduan wawancara memiliki isi yang valid.

Prosedur pengumpulan datapada penelitian ini dimulai dari surat keterangan lulus uji etik (ethical clearence) dan izin penelitian dari Fakultas Keperawatan Universitas Sumatera Utara (FKep USU). Sebelum melakukan wawancara terhadap partisipan pertama, peneliti melakukan pilot study yang dilakukan pada satu partisipan. Setelah itu, hasil wawancara dari pilot study dibuat dalam bentuk transkrip. Selanjutnya dikonsultasikan dengan ahli. Setelah mendapat persetujuan ahli, kemudian dilanjutkan oleh pendekatan (prolonged engagement) yang dilakukan kepada caregiver pasien strok kurang lebih selama dua minggu. Pada tahap ini, peneliti memperkenalkan diri, menjelaskan maksud, tujuan dan pengumpulan data yang dilakukan terhadap partisipan

Semua wawancara dilakukan dengan kondisi tenang, nyaman, dan menjaga privasi partisipan. Peneliti melakukan wawancara di rumah caregiver pasien strok dan meminta izin untuk merekam percakapan itu selama wawancara berlangsung. Pertanyaan yang diajukan selama wawancara berdasarkan panduan wawancara yang telah dibuat. Kemudian melanjutkan mengajukan berbagai pertanyaan menggunakan teknik probing. Teknik probing adalah cara peneliti untuk menggali informasi lebih jauh dengan menindaklanjuti topik yang terungkap dari partisipan. Setelah selesai, kemudian dilanjutkan dengan membuat transkrip hasil wawancara.

Peneliti melakukan analisis data dengan menggunakan pendekatan dari Colaizzi (1978). Tahapan metode analisis data dengan langkah-langkah antara lain: (1) Membaca dan menyalin seluruh deskripsi wawancara yang telah diungkapkan oleh partisipan; (2) Melakukan ekstraksi terhadap pernyataan yang signifikan (pernyataan yang secara langsung berhubungan dengan fenomena yang diteliti); (3) Menguraikan makna yang terkandung dalam pernyataan signifikan, (4) Menggabungkan makna yang dirumuskan ke dalam kelompok tema, (5) Mengembangkan sebuah deskripsi tema lengkap (yaitu deskripsi yang komprehensif dari pengalaman yang diungkapkan partisipan), (6) Mengidentifikasi landasan struktur dari fenomena tersebut, dan (7) Kembali kepada partisipan untuk melakukan validasi.

\section{Hasil Penelitian}

Hasil penelitian pada karekteristik partisipan didapatkan mayoritas caregiver mempunyai jenis kelamin perempuan $(93,8 \%)$, usia caregiver berada pada 46-55 tahun (50\%), beragama Islam $(81,2 \%)$, bersuku Batak $(68,8 \%)$, pendidikan terakhir SMA $(56,2 \%)$, pekerjaan IRT atau tidak bekerja $(62,5 \%)$, hubungan dengan pasien sebagai istri $(50 \%)$, lama merawat pasien satu sampai tiga tahun $(43,8 \%)$, pengobatan yang dilakukan secara medis dan juga tradisional $(43,8 \%)$, ketidakmampuan derajat 4 sebesar $56,2 \%$, dan tingkat ketergantungan berat $(56,2 \%)$.

Hasil dari analisis didapatkan lima tema dari pengalaman caregiver dalam merawat pasien strok di rumah. Tema pertama yaitu memberikan dukungan total. Bantuan dan dukungan yang diberikan caregiver selama merawat penderita strok di rumah dilakukan secara total mencakup berbagai aspek kehidupan, mulai dari dukungan moril, finansial, lingkungan fisik, dan pengobatan. Seorang partisipan mengungkapkan bahwa partisipan selalu mendahulukan kepentingan penderita strok diatas kepentingan pribadi 
Nanda Masraini Daulay: Study Fenomenologi: Pengalaman Keluarga sebagai Caregiver

partisipan. Ungkapan tersebut dapat terlihat di bawah ini:

“...saya ini dulu lah saya siapkan makannya, mandinya, baru saya makan, baru saya apa mandi, pokoknya semua saya apakan lah kakak ini kepentingannya, saya kasian juga lah nengoknya." [P9]

Beberapa partisipan mengungkapkan bahwa mereka telah melakukan beberapa modifikasi dari kamar mandi dan kamar tidur untuk memfasilitasi penderita strok dalam pemenuhan kebutuhan dasarnya. Ungkapan partisipan tersebut dapat dilihat sebagai berikut:

“..iya, di usahakan semua pegang ini ya pak, kalok mau duduk ini kursinya, kalok mau ke belakang nanti dorong kursinya pake tangan, makanya kalok kebelakang dia, berisik, di dorongnya kursinya, jalan dia ke belakang,. iya, tempat tidurnya pun saya pisahkan, tapi gak pake kasur saya bikin,..” [P7]

Tema yang kedua adalah dalam memenuhi kebutuhan dasar. Pasien strok mengalami kelemahan dan kelumpuhan fisik sehingga hampir semua kebutuhan dasar penderita strok harus dibantu oleh caregiver, seperti kebutuhan fisiologis, rasa aman dan nyaman, dan kebutuhan Spiritual.

Kebutuhan eliminasi penderita strok juga sering dikeluhkan caregiver dalam membantu untuk BAB dan BAK. Hal ini diungkapkan beberapa partisipan antara lain:

"Jadi kubantulah dia, mau BAB kan, kuangkatkan kakinya, kubantu dia sementara nunggu dokter diangkat kaya gini, yaudah gapapa abis itu. hmm kalau sekarang kadang kencing dulu kan sampai dua kali baru aku pampersin. Takutnya kecepatan kadang kan nanti bocor.." [P14]

Kebanyakan penderita strok mengalami ketergantungan partial care dan total care, sehingga untuk melakukan self care tentu saja harus dibantu caregiver. Beberapa partisipan mengungkapkan hal tersebut sebagai berikut:

“,soalnya kami kan orang karo, kalok misalnya la adekku yang mandikan kan malu, ya aku sendiri la yang mandikan. udah selesai saya lap smua, saya kasi sarung, baru kami angkat lagi ke rumah, dirumah, ditutup tirai gitu baru saya apakan, di lap smua, di bajui." [P16]

Tema yang ketiga adalah penderitaan dan hikmah bagi seorang caregiver. Banyaknya tugas caregiver yang selama bertahun-tahun merawat penderita strok mengakibatkan dampak berupa penderitaan. Akan tetapi, banyak hikmah bagi hidup caregiver.

Penderitaan caregiver yang didapatkan dari wawancara terdiri dari sub-kategori dampak fisik, dampak psikologis, dan dampak sosial. Hal tersebut di atas diungkapkan oleh beberapa caregiver sebagai berikut:

"Lelah, kadang pinggang, kebetulan kan melahirkan operasi, jadi memapah bouk ke kamar mandi, Demam, flu, tapi sakitnya sampe berobat-berobat ke klinik karna kecapean memang. " [P1]

Selain dampak fisik, ternyata yang paling dikeluhkan caregiver adalah dampak psikologis yang dirasakan selama merawat penderita. Berikut ini adalah ungkapan beberapa partisipan:

"Frustasi ya itu tadi kadang yang dibilangnya kadang bouk nangis ya sedih juga, tapi berarti kami yang gak beres merawat dia,," [P10]

Tema keempat adalah kebutuhan caregiver. Kebanyakan caregiver adalah orang awam yang memang baru pertama kali merawat penderita strok, sehingga caregiver kurang memiliki keterampilan dalam merawat anggota keluarga yang menderita strok. Karena itu mereka membutuhkan edukasi dan informasi.

Caregiver juga mengungkapkan bahwa kebutuhan akan edukasi dan informasi ini penting karena mereka merasa bingung dan tidak tahu cara merawat penderita strok yang sebenarnya. Hal ini terlihat dari pernyataan berikut ini:

"Kalok maunya saya sih diterapkan semuanya, mulai dari obatnya, kemudian kapan berhenti obatnya, kapan ditambah, dan bagaimana menghadapi mertua yang seperti itu psikisnya, " [P1]

Tema yang kelima adalah keterbatasan Caregiver. Dalam menjalankan perannya, caregiver memiliki banyak keterbatasan 
Nanda Masraini Daulay: Study Fenomenologi: Pengalaman Keluarga sebagai Caregiver

seperti keterbatasan finansial, fasilitas serta masalah fisik.

Keterbatasan fisik yang caregiver alami ditentukan dari berbagai faktor yang dibagi menjadi dua sub-kategori yaitu penyakit yang dialami caregiver dan fisik yang lemah. Hal ini diungkapkan beberapa caregiver antara lain:

",ada anak kos, orang sebelah-sebelah ini mintak tolong, biar di angkatkan ke kursi roda. pernah kami sekali, perempuan 3, nenek yang nyuci, yeni, sama sebelah, kami bertiga, jatuh gak bisa, gak kuat.” [P3]

Kurangnya biaya merupakan keterbatasan caregiver sehingga tidak bisa maksimal dalam merawat penderita strok. Hal ini sering dikeluhkan oleh caregiver sebagai keterbatasannya, seperti yang diungkapkan salah satu caregiver di bawah ini:

"Lupa ibu, ga ada mempannya. Terakhir di panggil ponco kerumah, terapi disini, gak sanggup ibu lagi, sudah habis duit berobatnya. Dikasih obat dia dari dokter saraf segini banyaknya Capek, kalau berobat dia satu setengah juta, darimana duit ?" [P2]

\section{Pembahasan}

Hasil wawancara pada tema yang pertama yakni memberikan dukungan total adalah dukungan yang diberikan caregiver mencakup seluruh aspek kehidupan penderita strok. Caregiver memberikan dukungan dalam bentuk dukungan moril, finansial, lingkungan fisik, dan memberikan pengobatan. Dukungan yang diberikan oleh caregiver adalah penting untuk membantu kesembuhan penderita strok baik dari segi fisik, psikososial, dan spiritual. Seorang partisipan mengungkapkan bahwa partisipan selalu disamping penderita strok dan tidak pernah meninggalkan penderita strok. Hal ini sesuai dengan teori keperawatan yang dibuat oleh Williams (2007), bahwa seorang caregiver harus memiliki komitmen selama merawat pasien. Komitmen tersebut mencakup bertanggung jawab, menjadikan pasien prioritas, selalu ada memberikan dukungan, dan keyakinan akan kasih sayang.

Keterlibatan anggota keluarga dalam peran caregiver pasien strok adalah kejadian yang tak terduga oleh keluarga pasien strok.
Keluarga penderita strok merasa bahwa mereka berkewajiban secara moral, dan tidak punya pilihan selain untuk menerima peran caregiver dan mereka menganggap caregiver sebagai 'bagian integral dari kehidupan' dan sebagai 'tugas yang tidak dapat dihindari' (Jones \& Morris, 2012).

Kegiatan yang dilakukan oleh caregiver selama merawat penderita strok adalah turut mendampingi penderita strok untuk berobat, memfasilitasi hingga membantu dalam aplikasi pengobatan tersebut. Akibat kecacatan yang dialami hampir sebagian besar penderita strok, rata-rata partisipan membawa penderita strok ke pengobatan medis dan juga alternatif. Beberapa partisipan mengungkapkan bahwa pasien yang lebih cepat pemulihannya setelah mendapatkan pengobatan alternatif disamping setelah mendapatkan pengobatan medis. Data demografi dari penggunaan pengobatan medis dan pengobatan tradisional menunjukkan bahwa sebesar $43,8 \%$ caregiver memberikan pengobatan pasien strok dengan kombinasi dari pengobatan medis dan tradisional. Dalam penelitian yang dilakukan Varghese (2004) disebutkan bahwa pengaruh sosial memang sangat kompleks salah satunya adalah pengaruh orang lain atau sugesti teman memiliki angka $11,59 \%$ dari alasan pemilihan pengobatan alternatif, sebesar $13,04 \%$ responden menyatakan pengobatan alternatif dipilih karena alasan murah.

Hasil dari penelitian didapatkan mayoritas partisipan bersuku Batak (68,8\%) dan beragama Islam $(81,2 \%)$. Nilai-nilai budaya yang dominan pada diri individu sangat memengaruhi pembentukan kepribadian seseorang. Selanjutnya, kepribadian tersebut akan menentukan pola dasar perilaku manusia, termasuk perilaku dalam hal memilih pengobatan (Notoatmodjo, 2005).

Hasil wawancara pada tema kedua yakni membantu memenuhi kebutuhan dasar. Penderita strok mengalami kelemahan dan kelumpuhan fisik sehingga hampir semua kebutuhan dasar pasien harus dibantu oleh caregiver. Berdasarkan hasil analisis tema, kebutuhan dasar yang dibantu oleh caregiver antara lain kebutuhan fisiologis, kebutuhan rasa aman dan nyaman, dan kebutuhan spiritual. 
Nanda Masraini Daulay: Study Fenomenologi: Pengalaman Keluarga sebagai Caregiver

Penelitian yang dilakukan oleh Arksey dan Hirst (2005) terhadap 80 caregiver di Inggris menyebutkan bahwa secara umum, caregiver memberikan bantuan dalam eliminasi pasien baik buang air kecil maupun buang air besar, membantu self care pasien, dan mobilisasi pasien. Selain itu, Milligan (2005) dalam penelitiannya menarik perhatian terhadap caregiver pada lansia. Tugas yang dilakukan caregiver tidak hanya terbatas kepada pekerjaan rumah tangga, akan tetapi dibagi ke dalam empat kategori yaitu, physical care atau perawatan fisik, social care atau kepedulian sosial, emotional care, dan quality care.

Hasil dari penelitian ini ditemukan juga bahwa beberapa caregiver juga membantu dalam memenuhi kebutuhan spiritualitas penderita strok. Hasil penelitian didapatkan bahwa mayoritas partisipan beragama Islam $(81,2 \%)$. Beberapa partisipan yang beragama Islam mengungkapkan bahwa mereka memfasilitasi pasien strok ketika akan berwudhu dan menjalankan sholat. Hal ini dikaitkan dengan kepercayaan atau ajaran agama yang menganjurkan untuk beribadah baik ketika keadaan sehat maupun sakit dan ketika senang maupun sulit.

Hasil tema yang ketiga yakni penderitaan dan hikmah bagi caregiver. Caregiver pada penderita strok memiliki tugas yang sangat berat karena hampir seluruh aspek kehidupan pasien strok tergantung bantuan dari caregiver. Banyaknya tugas caregiver yang selama bertahun-bertahun merawat pasien strok mengakibatkan dampak yaitu, penderitaan dan hikmah dalam hidup seorang caregiver. Mayoritas caregiver mengeluhkan banyaknya penderitaan selama merawat penderita strok. Hasil penelitian menunjukkan penderitaan yang dirasakan caregiver mencakup dampak fisik, psikologis, dan sosial.

Penderitaan yang caregiver alami dimulai ketika mereka pertama kali diberitahukan tentang diagnosis pasien. Selama pasien di rumah sakit, perhatian besar caregiver adalah kondisi kesehatan pasien dan ketakutan bahwa pasien dapat saja meninggal. Hanya setelah kesehatan pasien stabil, caregiver mulai kembali ke kehidupan rutin mereka dan melakukan banyak pekerjaan (Pierce, Thompson, Govoni \& Steiner, 2012; Kerr
\& Smith, 2000). Hasil data demografi menunjukkan bahwa mayoritas partisipan merawat pasien strok selama satu sampai dengan tiga tahun sebesar $43,8 \%$.

Penelitian yang dilakukan oleh Pierce, Steiner, Govoni, Thompson dan Firdemann tahun 2007 menunjukkan bahwa caregiver akan berhasil dalam menjalankan tugasnya dalam merawat pasien strok dalam rentang satu tahun ke atas. Mulai kurun waktu tiga sampai dengan enam bulan pertama setelah serangan strok, caregiver masih berusaha untuk menerima kondisi pasien strok, belajar untuk menyesuaikan diri dengan keadaan, dan belajar cara merawat pasien strok. Sehingga dalam penelitian ini, beberapa caregiver yang merawat pasien strok lebih dari satu tahun mengeluh mengalami beban psikologis dan stres dalam merawat anggota keluarga yang menderita strok. Berbeda dengan hasil penelitian tersebut, caregiver yang sudah merawat pasien strok lebih dari tiga tahun justru merasa stres dan mengalami beban fisik dan psikologis karena jenuh dan putus asa merawat anggota keluarga yang menderita strok dan tidak kunjung sembuh.

Banyak caregiver penderita strok adalah lansia yang merupakan pasangannya dan mungkin rentan terhadap masalah kesehatan yang serius atau sebelumnya memiliki sejarah penyakit kronis. Saat yang sama, caregiver menderita masalah akibat perawatan pasien antara lain terkait masalah fisik seperti kelelahan, keletihan, pusing, masalah tidur, nyeri, dan kelemahan (Jullamate, P., Azeredo, Z., \& Subgranom, R., 2006; Pierce dkk., 2012) .

Strok sebagai peristiwa yang traumatis, dampaknya tidak hanya pada orang yang terkena, tetapi juga seluruh keluarga. Stres, marah, temperamen, melukai perasaan, putus asa, ketidaknyamanan, dan kejenuhan adalah beberapa konsekuensi emosional negatif dari caregiver (Jullamate, dkk., 2006; Pierce, 2001; Pierce, dkk., 2012; Jones \& Morris, 2012).

Rasa ketidakpastian umumnya dialami oleh seorang caregiver. Selama pertemuan dengan tim perawatan kesehatan, adanya kesadaran mengenai potensi penderitaan caregiver karena perawat terlalu sibuk, saling berhubungan dengan pertanyaan yang belum terjawab dan kegagalan tim kesehatan dalam 
Nanda Masraini Daulay: Study Fenomenologi: Pengalaman Keluarga sebagai Caregiver

memberikan informasi yang cukup dan benar mengenai penyakit menjadi pencetus ketidakpastian (Jullamate, dkk., 2006).

Perubahan perilaku pada pasien, masalah keuangan, dukungan yang tidak memadai, tugas caregiver terlalu banyak, dan kesulitan tidur bisa menjadi sumber caregiver distress (Pierce, dkk., 2012). Caregiver berjuang untuk mengelola kondisi kehidupan yang sulit dengan menerapkan strategi koping yang berbeda seperti, tetap positif, menjadi fleksibel dengan perubahan yang mendadak, membandingkan hal baru dengan pengalaman merawat pasien sebelumnya, menggunakan humor, dan dukungan keluarga dan temanteman (Jones \& Morris 2012). Terlibat dalam kegiatan keagamaan dengan mengandalkan sistem dukungan sosial dan tokoh agama, kemampuan koping yang penting untuk meningkatkan kehidupan caregiver dan memelihara kesejahteraan fisik dan emosional mereka (Jullamate, dkk., 2006).

Arksey dan Hirst (2005) menemukan terdapatnya masalah kesehatan mental yang timbul secara langsung terhadap caregiver dalam proses perawatan pasien. Hasil penelitian menunjukkan bahwa caregiver yang memberikan perawatan kepada pasien atau keluarga lebih dari 20 jam atau lebih per minggu adalah dua kali lipat berisiko mengalami tekanan psikologis dan efek ini lebih besar pada caregiver wanita. Penelitian yang dilakukan Kalliath dan Kalliath (2000) di Selandia Baru pada caregiver pasien strok, menemukan terdapat kelelahan emosional yang dikaitkan dengan gejala kelelahan, depersonalisasi, dan penurunan prestasi pribadi. Cameron, Cheung, Streiner, Coyte, dan Stewart (2006) menemukan sebesar $44 \%$ dari 94 orang caregiver berkebangsaan Canada pada pasien strok berisiko terkena depresi klinis.

Hasil survey yang dilakukan oleh Vitaliano dan Zhang $(2003,2004)$ menemukan dampak kesehatan fisik bagi caregiver pada lansia dengan demensia. Penelitian tersebut mengungkapkan bahwa caregiver melaporkan mengalami gangguan kesehatan fisik dan membutuhkan pengobatan yang lebih sering dibandingkan yang bukan caregiver. Sebesar $23 \%$ terjadi peningkatan hormon stres pada caregiver. Hasil lain menunjukkan bahwa caregiver menghasilkan produksi antibodi yang rendah, tingginya gangguan tidur dan kurang adekuatnya diet.

Selain penderitaan caregiver di atas, ternyata proses caregiving yang dilakukan oleh caregiver juga memiliki hikmah bagi kehidupannya. Hal ini diungkapkan partisipan bahwa selama merawat penderita strok dapat lebih menjaga kesehatannya, meningkatkan spiritualitas, dan pasien menjadi lebih dekat dengan keluarga selama sakit. Penelitian yang dilakukan oleh Nikora, Karapu, Hickey, dan Te Awekotuku (2004) di Selandia Baru menemukan bahwa menjadi caregiver dapat menambah pengalaman, ilmu, serta dapat meningkatkan spiritualitas.

Tema keempat adalah kebutuhan caregiver Kebanyakan caregiver adalah orang awam yang memang baru pertama kali merawat penderita strok, sehingga ada beberapa keterampilan yang diperlukan oleh caregiver untuk memudahkan pekerjaannya dalam merawat pasien strok. Tema ini terdiri dari dua kategori yaitu kebutuhan edukasi dan informasi juga kebutuhan psikologis.

Penelitian Yedidia dan Tiedemann, (2008) berdasarkan tugas caregiver menyimpulkan kebutuhan caregiver yaitu: (1) Kebutuhan akan informasi tentang pelayanan yang tersedia; (2) Manajemen stress dan strategi koping; (3) Masalah keuangan dan asuransi; (4) Masalah komunikasi dengan profesional kesehatan; (5) Informasi tentang penyakit; (6) Menggunakan bantuan yang kompeten; (7) Bantuan tentang tugas-tugas perawatan; (8) Bantuan berkomunikasi dengan pasien; (9) Nasihat hukum; (10) Informasi tentang obat; (11) Bantuan mengatasi masalah akhir kehidupan; (12) Panduan memindahkan pasien kepada fasilitas yang mendukung; dan (13) Bantuan berurusan dengan keluarga.

Secara umum pelayanan kesehatan lebih ditujukan bagi penderita strok, sedangkan kebutuhan caregiver belum terselesaikan. Caregiver seringkali salah mengerti tentang istilah strok. Oleh karena itu, mereka termotivasi untuk menemukan sumbersumber lain selain tim kesehatan untuk mendapatkan informasi dan untuk belajar keterampilan caregiving dengan cara yang kompeten dan percaya diri. Kadang-kadang, mencari informasi yang diperlukan bisa sulit dan frustasi untuk keluarga (Jullamate, dkk., 
Nanda Masraini Daulay: Study Fenomenologi: Pengalaman Keluarga sebagai Caregiver

2006).

Kurang memadainya persiapan untuk melakukan tugas-tugas caregiving sering disorot (Cobley, Fisher, Chouliara, Kerr, \& Walker, 2012). Menyediakan caregiver dengan harapan yang realistis, kepastian, informasi yang diperlukan, dan pelatihan keterampilan fisik sangatlah penting. Untuk merasa yakin tentang keterampilan, caregiver membutuhkan umpan balik yang konstruktif dan memvalidasi praktik mereka dari tenaga pelayanan kesehatan profesional (Kerr \& Smith, 2000).

Ketidakpuasan dan keluhan tentang kurangnya perawatan holistik multidisipliner yang diterima dari institusi terkait membuat caregiver menginginkan tim kesehatan profesional dapat memfasilitasi peran mereka menjadi lebih baik dalam mengkoordinasikan perawatan yang diberikan, membantu dalam kemajuan pasien dan pengasuh kehidupan menuju normal, menerapkan penguasaan peran caregiving, dan memiliki sumber daya yang dapat diakses masyarakat.

Keluarga penderita strok merasa bahwa dalam bekerja, akan lebih mudah bagi mereka untuk memberikan perawatan yang aman dan kompeten jika mereka menerima dukungan profesional dan sosial yang memadai (Jullamate, dkk., 2006). Hal ini penting bagi tim pelayanan kesehatan untuk membangun hubungan suportif dengan caregiver, dan peran profesional perawatan kesehatan harus diperluas untuk mencakup tindak lanjut kunjungan ke rumah caregiver. Sebuah penilaian kebutuhan keuangan, layanan rujukan yang tepat, dan peralatan terjangkau ditekankan kebutuhan sebagai yang diidentifikasi oleh caregiver (Ang, dkk., 2013). Namun, kepuasan caregiver oleh dukungan dan layanan masyarakat jarang didokumentasikan.

Tema yang kelima adalah keterbatasan caregiver. Dalam menjalankan perannya, caregiver memiliki banyak keterbatasan yang dibagi menjadi tiga kategori yaitu faktor masalah fisik, faktor finansial, dan faktor fasilitas. Faktor masalah fisik yang dialami caregiver mencakup dari sakit yang dialami caregiver, jenis kelamin caregiver dan pasien yang dirawat, juga juga faktor usia caregiver.

Adapun jenis kelamin partisipan mayoritas adalah perempuan $(93,8 \%)$, sedangkan jenis kelamin penderita strok yang terbanyak adalah laki-laki (56,2\%). Usia caregiver berada pada rentang 46-55 tahun (50\%). Sebagian besar caregiver berjenis kelamin wanita. Blackburn dan Kosloski (2007) mengungkapkan bahwa wanita diketahui memiliki waktu istirahat dan latihan yang kurang dibandingkan pria. Sehingga terjadi perubahan kardiovaskuler seperti tekanan darah meningkat. Kurangnya waktu untuk merawat diri sendiri karena permintaan rawatan yang berkesinambungan dapat berdampak negatif pada kesehatan caregiver.

Karekteristik penderita strok berupa faktor usia menimbulkan pengaruh pada masalah penurunan kemampuan fisik, memerlukan bantuan untuk perawatan fisik dan masalah administrasi yang mengarah kepada ketegangan dan stres caregiver. Segi pengaturan hidup seorang caregiver dengan adanya perpindahan pasien dari rumah ke rumah sakit atau sebaliknya menimbulkan distres. Karekteristik penderita strok berupa usia, jenis kelamin, pekerjaan, status finansial, status pernikahan, pengaturan hidup dan peran biasanya, ini perlu dipertimbangkan dalam kontribusinya terhadap beban caregiver.

\section{Simpulan}

Hasil dari penelitian ini dapat disimpulkan bahwa sebuah pengalaman keluarga sebagai caregiver dalam merawat penderita strok di rumah terkait dengan memberikan dukungan secara total, membantu dalam memenuhi kebutuhan dasar, penderitaan dan juga hikmah bagi caregiver, kurangnya keterampilan dalam merawat, dan keterbatasan seorang caregiver. Adapun kebutuhan caregiver dalam merawat pasien strok adalah kebutuhan edukasi, informasi, dan psikologis. Berdasarkan hasil penelitian, disarankan perencanaan pulang pasien strok lebih berpusat pada keluarga daripada pendekatan berpusat pada pasien.

\section{Daftar Pustaka}

Abubakar, S. A., \& Isezuo, S. A. (2012). Health related quality of life of stroke survivors: Experience of a stroke unit. 
Nanda Masraini Daulay: Study Fenomenologi: Pengalaman Keluarga sebagai Caregiver

International Journal of Biomedical Science, 8(3), 183-187.

Akosile, C. O., Okoye, E. C., Nwankwo, M. J., Akosile, C. O., \& Mbada, C. E. (2011). Quality of life and it's correlates in caregivers of strok survivors from Nigerian population. Springer Science: Qual Life Research 20(9), 1379-1384. doi: 10.1007/s11136-011-98769.

Arksey, H., \& Hirst, M. (2005). Unpaid carers' access to and use of primary care services. Primary Health Care Research and Development, 6(02), 101-116.

Blackburn, J. A., \& Dulmus, C. N. (Eds.). (2007). Handbook of gerontology: Evidencebased approaches to theory, practice, and policy. John Wiley \& Sons.

Cameron, J. I., Cheung, A. M., Streiner, D. L., Coyte, P. C., \& Stewart, D. E. (2006). Stroke survivors' behavioral and psychologic symptoms are associated with informal caregivers' experiences of depression. Archives of Physical Medicine and Rehabilitation, 87(2), 177-183.

Cobley, C. S., Fisher, N. C., Kerr, M., \& Walker, M. F. (2013). A qualitative study exploring patients' and carers' experiences of early supported discharge services after stroke. Clinical Rehabilitation Journal, 27(8), 1-8, doi: 10.1177/0269215512474030.

Colaizzi, P. (1978). Psychological research as the phenomenologist's view it. In R. Vale \& M. King (Eds.), Existential-phenomenological alternatives for psychology , 48-71. New York: Oxford University Press.

Departemen Kesehatan RI. (2013). Riset Kesehatan Dasar (Riskesdas): Laporan Nasional 2013. Jakarta: Badan Penelitian dan Pengembangan Kesehatan Depkes RI.

Departemen Kesehatan RI. (2012). Profil kesehatan Indonesia 2011. Jakarta: Depkes RI.

Given, B. A., Given, C. W,. \& Sherwood, R. P. (2011). Family \& caregiver needs over the course of the cancer trajectory. The Journal of Supportive Oncology, 10(2), 57-64.

Given, B., Wyatt, G., Given, C., Sherwood, P., Gift, A., Devoss, D., \& Rahbar, M. (2004). Oncology Nursing Forum, 6(31), doi:10.1188/04. onf. 1105-1117.

Jones, L., \& Morris, R. (2012). Experiences of adult stroke survivors and their parent carers: A qualitative study. Clinical Rehabilitation Journal, 27(3), 272-280. doi: $10.1177 / 0269215512455532$.

Jullamate, P., Azeredo, Z., \& Subgranom, R. (2006). Thai stroke patient caregivers: Who they are and what they need. Europe PubMed Central, 21(1-2):128-133. doi: 10.1159/000090211.

Kalliath, P., \& Kalliath, T. (2000). Understanding caregiver burnout: Social worker's role in assisting caregivers of long term stroke survivors. Social Work Review.

Kerr, S. M \& Smith, L. N. (2000). Stroke: An exploration of the experience of informal caregiving. Clinical Rehabilitation 2001 15: 428. doi: 10.1191/026921501678310234.

Nikora, L. W., Karapu, R., Hickey, H., \& Te awekotuko, N. (2004). Disabled Maori and dsability support option: A report prepared for the Ministry of Health Hamilton Office. Hamilton, New Zealand. Maori and Psychology Research Unit, University of Waikato.

Pierce, L. L. (2001). Caring and expressions of stability by urban family caregivers of persons with strok within African American family system. Rehabilitation Nursing Journal, 26(3), 100.

Pierce, L. L., Steiner, V., Govoni, A., Thompson, T. C., \& Friedemann, M. L. (2007). Two sides to the caregiving story. Thomas Land Publishers, Inc. Top Stroke Rehabilitation. doi: 10.1310/tsr1402-13.

Pierce, L. L., Thompson, T. L., Govoni, A. L., \& Steiner, V. (2012). Caregivers' incongruence: Emotional strain in caring for 
Nanda Masraini Daulay: Study Fenomenologi: Pengalaman Keluarga sebagai Caregiver

persons with stroke. Rehabilitation Nursing Journal, 37(5), 258. doi: 10. 1002/rnj.035.

Piercy, K., \& Chapman, J. Adopting the caregiver role: A family legacy. Family Relations 2001, 50. 386-393.

Varghese, C. T. (2004). Is patient's preference for medical changing?. Diakses dari http:// www.medicaholistic.com.

Vitaliano, P. P., Young, H. M., \& Zhang, J. (2004). Is caregiving a risk factor for illness?. Current Directions in Psychological Science, 13(1), 13-16.

Vitaliano, P. P., Zhang, J., \& Scanlan, J. M. (2003). Is caregiving hazardous to one's physical health? A meta-analysis. Psychological Bulletin, 129(6), 946-972.
Williams, L. A. (2007, January). Whatever it takes: Informal caregiving dynamics in blood \& marrow transplantation. Oncology Nursing Forum, 34(2), 379-387.

Wodchis, W. P., Maxwell, C. J., Venturini, A., Walker, J. D., Zhang, J., Hogan, D. B., \& Feeny, D. F. (2007). Study of observed and self-reported HRQL in older frail adults found group-level congruence and individual-level differences. Journal of Clinical Epidemiology, 60(5), 502-511.

Yayasan Stroke Indonesia. (2009). Strok bisa ganggu sosial ekonmi keluarga. Diakses dari: http:// www.yastroki.or.id/read.php?id=310

Yedidia, M. J., \& Tiedemann, A. (2008). How do family caregivers describe their needs for professional help?. AJN The American Journal of Nursing, 108(9), 35-37. 